\title{
Pengaruh Model Pembelajaran Inkuiri Terbimbing Integrasi Peer Instruction terhadap Kemampuan Berpikir Kritis Siswa SMA pada Materi Laju Reaksi
}

\author{
Chintia Dewi ${ }^{1}$, Lisa Utami ${ }^{2}$, Zona Octarya ${ }^{3}$ \\ ${ }^{123}$ Program Studi Pendidikan Kimia, Universitas Islam Negeri Sultan Syarif Kasim Riau. \\ e-mail: \\ 1tiadew04@yahoo.com \\ 21154_lazoelva@yahoo.com \\ 3zona.octarya@uin-suska.ac.id
}

\begin{abstract}
.
This research aimed at knowing the effect of implementing peer instruction integrated guided inquiry model on reaction rate lesson toward student critical thinking ability. it was conducted at the first semester in the academic year of 2018/2019, and it was on reaction rate lesson at the eleventh-grade students of natural science 1 and 2 of state senior high school 2 tapung, kampar regency. it was a quasi-experiment with pretest-posttest group experimental design. 51 students were the samples, and purposive sampling technique was used in this research. instruments were essay test in the form of pretest and posttest and observation sheet. the obtained data showed that there was a significant effect of peer instruction integrated guided inquiry model on reaction rate lesson toward student critical thinking ability, about $8,4 \%$.
\end{abstract}

Keywords: guided inquiry, peer instruction, critical thinking ability, reaction rate.

\begin{abstract}
ABSTRAK.
Penelitian ini bertujuan untuk mengetahui pengaruh penerapan model pembelajaran inkuiri terbimbing integrasi peer instruction pada materi laju reaksi terhadap kemampuan berpikir kritis siswa. Penelitian ini dilaksanakan pada 2 kelas yaitu XI MIA 1 dan XI MIA 2 SMA Negeri 2 Tapung Kabupaten Kampar tahun ajaran 2018/2019. Jenis penelitian ini adalah quasi eksperimen dengan design pretes-postes. Sampel sebanyak 51 orang siswa dengan teknik pengambilan sampel purposive sampling. Instrumen penelitian berupa tes essay dan lembar observasi. Data yang diperoleh menunjukkan bahwa terdapat pengaruh yang signifikan dari penerapan model pembelajaran inkuiri terbimbing integrasi peer instruction pada materi laju reaksi terhadap kemampuan berpikir kritis siswa sebesar $8,4 \%$.
\end{abstract}

Kata kunci: inquiri terbimbing, berpikir kritis, laju reaksi

\section{PENDAHULUAN}

Berkembangnya arus teknologi dan informasi, membuat akses tenaga kerja semakin dinamis. Memasuki Masyarakat Ekonomi Asean (MEA) dan Asean Free Trade Area (AFTA) pada tahun 2016-2017, menuntut adanya persiapan sumber daya manusia. Indonesia harus meningkatkan kualitas sumber daya manusia agar memiliki kemampuan bersaing dengan tenaga kerja dari negara lain. Salah satu upaya untuk meningkatkan kualitas sumber daya manusia adalah 
melalui peningkatkan kualitas pendidikan. Peningkatan kualitas pendidikan akan menghasilkan siswa yang berkompeten, mampu bersaing dalam era global.

Terdapat 4 kemampuan yang harus dimiliki siswa, agar nantinya mampu berkompetisi dalam era global yaitu, kemampuan berpikir kritis, kemampuan berkomunikasi, kemampuan berkerja sama dan kreativitas (Agustin, 2016). Salah satu kemampuan yang dapat dilatih dan dikembangkan dalam pembelajaran IPA adalah kemampuan berpikir kritis. Kemampuan untuk berpikir kritis merupakan usaha sadar seseorang dalam memutuskan apa yang harus dilakukan atau dipercayai dengan memfokuskan pemikiran seseorang kepadanya. Richard Paul mendefinisikan pemikiran sebagai disiplin berpikir dan diarahkan dari dalam diri yang mengeksploitasi kesempurnaan pemikiran yang sesuai dengan mode atau ranah pemikiran tertentu. Weinstein mengemukakan kerangka pemikiran kritis yang mencakup pemikiran terampil, berpikir bertanggung jawab, pemikiran non rutin, menerapkan kriteria, koreksi diri, dan kepekaan (Arantika et al., 2014).

Ilmu kimia termasuk kedalam rumpun dari IPA. Salah satu yang perlu dikembangkan dalam pembelajaran kimia yaitu kemampuan berpikir kritis, sebab kemampuan berpikir kritis merupakan kemampuan penting yang harus dikembangkan untuk mengantarkan siswa mencapai tujuan pembelajaran secara optimal. Pembelajaran kimia di sekolah sebaiknya dapat dihubungkan dengan lingkungan sekitar agar siswa mampu menyelesaikan permasalahan kimia yang terdapat dalam kehidupan sehari-hari dan melatih kemampuan berpikir kritis. Namun kenyataannya pelaksanaan pembelajaran kimia di sekolah cenderung kurang memperhatikan kemampuan berpikir kritis (Ayu et al., 2016).

Berdasarkan hasil wawancara dengan guru kimia SMA Negeri 2 Tapung diperoleh informasi bahwa ada beberapa kelas terutama di kelas XI yang masih memiliki ketuntasan dibawah KKM dalam mempelajari materi Laju Reaksi sehingga harus mengikuti pembelajaran remedial. Penyebab kesulitan siswa dalam mendapatkan nilai di atas KKM adalah kurangnya rasa ingin tahu siswa seperti saat proses pembelajaran berlangsung siswa hanya mampu memberikan penjelasan sederhana terkait materi, pertanyaan-pertanyaan yang ditanyakan siswa masih bersifat dasar. Selain itu pada saat tanya jawab siswa hanya bertanya dan menjawab seadanya tanpa ada menganalisis kembali argumen-argumen yang disampaikan siswa lainnya. Berdasarkan hasil wawancara diketahui telah ada menunjukkan kemampuan berpikir kritis namun masih sebatas memberikan penjelasan yang sederhana.

Laju reaksi adalah salah satu materi kimia yang membutuhkan kemampuan berpikir kritis, yang diajarkan di kelas XI SMA/MA dan merupakan materi yang erat kaitannya dengan kehidupan sehari-hari (Fajariyah et al., 2016). Materi tersebut terdapat pada Kompetensi Dasar (KD) 4.7 yaitu merancang, melakukan, dan menyimpulkan serta menyajikan data hasil percobaan faktor-faktor yang mempengaruhi laju reaksi dan orde reaksi (Hani et al., 2016).

Model pembelajaran inkuiri terbimbing (Guided Inquiry), merupakan solusi perbaikan dan peningkatan kualitas pembelajaran yang cocok untuk mengatasi permasalahan yang muncul dalam pembelajaran (Hendra, 2011). Model pembelajaran inkuiri terbimbing tepat diterapkan pada kondisi kelas yang kemampuan siswanya bervariasi. Model pembelajaran inkuiri terbimbing adalah model pembelajaran yang berpusat pada siswa, siswa dilatih untuk mengembangkan kemampuan berpikir, khususnya kemampuan untuk berpikir kritis. Selain itu, dapat meningkatkan semangat belajar siswa. Model pembelajaran inkuiri terbimbing diterapkan agar para siswa bebas mengembangkan konsep yang mereka pelajari. Siswa diberi kesempatan untuk memecahkan masalah yang mereka hadapi secara individu atau berkelompok, di dalam kelas siswa dilatih untuk berinteraksi dengan kawan sebayanya untuk saling bertukar informasi (Kurniawati \& Diantoro, 2014).

Kelebihan dari model pembelajaran inkuiri terbimbing, yaitu siswa terlibat secara aktif dalam memberikan hipotesis, menyelidiki, mengumpulkan beberapa data untuk membuktikan 
hipotesis, mengkomunikasikan bukti-bukti yang diperoleh dengan teman dan guru agar mendapat simpulan yang jelas dan tepat. Adanya kesempatan siswa untuk mengemukakan ide dan pola pikir dalam menyelesaikan masalah yang tertera pada kegiatan pembelajaran yang menggunakan model pembelajaran inkuiri terbimbing berdampak pada munculnya rasa percaya diri siswa karena siswa merasa dihargai keberadaannya dalam proses pembelajaran, sehingga meminimalkan siswa yang mencontek atau tidak percaya pada kemampuan dirinya (Kartimi, 2013).

Namun berdasarkan observasi yang dilakukan kurniawati \& Diantoro, (2014) dalam penelitiannya masih ada siswa yang kurang aktif dalam pembelajaran menggunakan model inkuiri terbimbing. Kurang aktifnya siswa yaitu saat kegiatan diskusi dikarenakan suasana kelas yang ramai yang mengakibatkan konsentrasi siswa berkurang dalam penguasaan konsep. Sehinga perlu dilakukan integrasi model pembelajaran inkuiri dengan teknik atau metode pembelajaran lainnya supaya lebih efektif dan mampu mengoptimalkan aktivitas belajar siswa. Salah satu metode pembelajaran yang dapat mengoptimalkan keaktifan siswa dalam pembelajaran adalah peer instruction. Metode pengajaran interaktif peer instruction ini dikembangkan oleh Profesor Eric Mazur diawal tahun 1990 yang diterapkan pada mahasiswa fisika di Harvard University (Sulviani et al., 2013).

Pemilihan strategi penerapan model pembelajaran merupakan faktor yang sangat penting guna tercapainya prestasi belajar yang optimal. Dengan penggabungan dua pembelajaran yaitu inkuiri terbimbing integrasi peer instruction sebagai suatu model dan metode dalam melakukan pembelajaran kimia diharapkan mampu meningkatkan kemampuan kognitif, afektif, dan psikomotor siswa. Bilgin memaknai inkuiri terbimbing sebagai model pembelajaran student oriented. Model ini memiliki korelasi yang positif terhadap keberhasilan kognitif siswa dan meningkatkan keterampilan proses ilmiah mereka (Qing et al., 2012). Hasil penelitian oleh menunjukkan bahwa kemampuan penguasaan konsep siswa yang diberikan perlakuan inkuiri terbimbing integrasi peer instruction lebih tinggi daripada pembelajaran inkuiri terbimbing dan pembelajaran konvensional dan kemampuan berpikir kritis siswa yang belajar dengan pembelajaran inkuiri terbimbing integrasi peer instruction lebih tinggi daripada pembelajaran inkuiri terbimbing dan pembelajaran konvensional (Kurniawati \& Diantoro, 2014). Berdasarkan uraian di atas maka penulis melakukan penelitian yang berjudul pengaruh penerapan model pembelajaran inkuiri terbimbing integrasi peer instruction pada materi laju reaksi terhadap kemampuan berpikir kritis siswa.

\section{METODOLOGI}

Penelitian ini merupakan penelitian quasi eksperimen (eksperimen semu) dengan desain eksperimen pretest-posttest group. Dalam hal ini peneliti menggunakan dua kelas yaitu kelas eksperimen dan kelas kontrol. Kelas eksperimen diberi perlakuan dengan menggunakan model pembelajaran inkuiri terbimbing integrasi peer instruction, sedangkan kelas kontrol tanpa perlakuan inkuri terbimbing melainkan hanya menggunakan pendekatan saintifik. Kedua kelas terlebih dahulu diberikan pretest, setelah itu diberikan perlakuan dan selanjutnya diberikan posttest. Soal yang digunakan pada soal pretest dan posttest adalah sama. Gain nilai dari soal pretest dan posttest kelas eksperimen dan kelas kontrol merupakan data yang digunakan untuk melihat pengaruh penerapan model pembelajaran inkuiri terbimbing terhadap kemampuan berpikir kritis siswa .

Tabel 1. Desain penelitian pretest dan posttest

\begin{tabular}{llll}
\hline Kelompok & Pre-test & Perlakuan & Post-test \\
\hline Eksperimen & $\mathrm{T}_{1}$ & $\mathrm{X}_{1}$ & $\mathrm{~T}_{2}$ \\
\cline { 2 - 5 } Kontrol & $\mathrm{T}_{1}$ & $\mathrm{X}_{2}$ & $\mathrm{~T}_{2}$ \\
& & &
\end{tabular}


$\mathrm{X}_{1}=$ Perlakuan model pembelajaran inkuiri terbimbing integrasi peer instruction

$\mathrm{X}_{2}=$ Perlakuan pendekatan saintific

$\mathrm{T}_{2}=$ Data akhir (data setelah perlakuan)

Penelitian ini dilakukan di SMA Negeri 2 Tapung Kabupaten Kampar, Riau. Waktu penelitian sesuai dengan masalah yang diambil pada materi laju reaksi yang dipelajari di semester ganjil pada bulan Oktober 2018. Teknik pengambilan sampel yang digunakan dalam penelitian ini adalah purposive sampling dengan instrumen penelitian adalah tes, non tes. Tes yang digunakan adalah tes tertulis yaitu tes uraian (essay). Sebelum soal diberikan ke siswa, soal tes yang digunakan divalidasi terlebih dahulu. Soal diujicobakan kepada peserta didik dianalisis untuk mengetahui validitas, reabilitas, daya pembeda dan tingkat kesukaran soal.

Nilai dari data pretest yang diperoleh siswa diolah dengan menggunakan bantuan software SPSS versi 24.0 sesuai dengan kategori kemampuan berpikir kritis siswa. Nilai pretest ini bertujuan untuk melihat kemampuan berpikir kritis siswa sebelum diberi perlakuan dengan menggunakan model pembelajaran inkuiri terbimbing integrasi peer instruction. Sedangkan nilai posttest yang diperoleh bertujuan untuk mengetahui perbedaan setelah diberikan perlakuan yaitu model pembelajaran inkuiri terbimbing integrasi peer instruction. Data awal (pretest) dan data akhir (posttest) kemampuan berpikir kritis siswa kelas eksperimen dan kelas kontrol ini disajikan sebagai berikut:

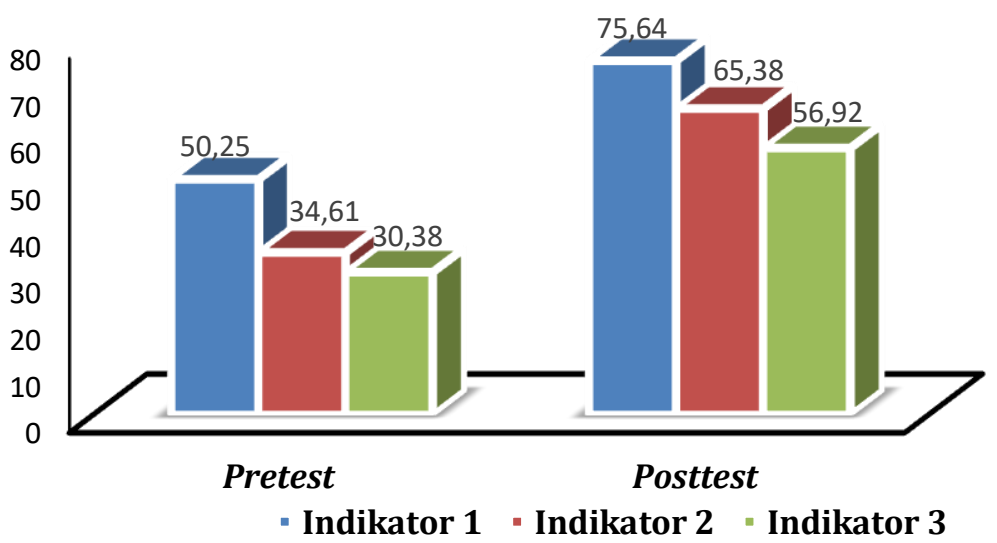

Gambar 1. Hasil pretest dan posttest per indikator kemampuan berpikir kritis kelas eksperimen

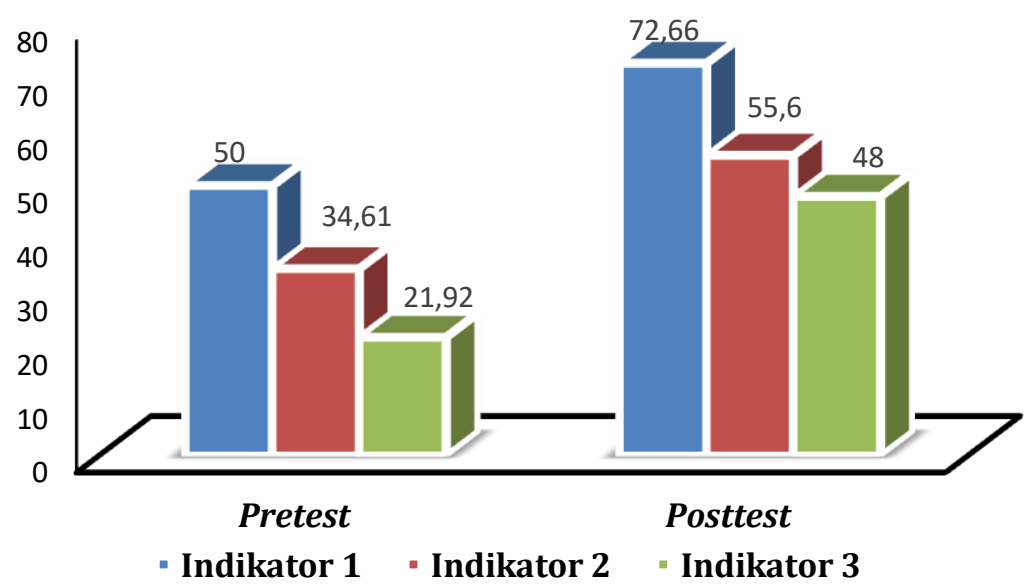

Gambar 2. Hasil pretest dan posttest per indikator kemampuan berpikir kritis kelas kontrol 
Data di atas menunjukkan hasil pretest dan posttest per indikator kemampuan berpikir kritis. Indikator 1 yaitu indikator memberikan penjelasan sederhana, indikator 2 yaitu membangun kemampuan dasar, dan indikator 3 yaitu menyimpulkan.

Observasi pada penelitian ini digunakan untuk mengetahui keterlaksanakan model pembelajaran inkuiri terbimbing integrasi peer instruction dan juga untuk melihat secara langsung bagaimana kemampuan berpikir kritis siswa. Peneliti menggunakan lembar observasi dalam melalukan observasi di kelas. Adapun data hasil observasi selama empat kali pertemuan pada kelas ekperimen dan kontrol disajikan sebagai berikut:

\section{Kelas Eksperimen}

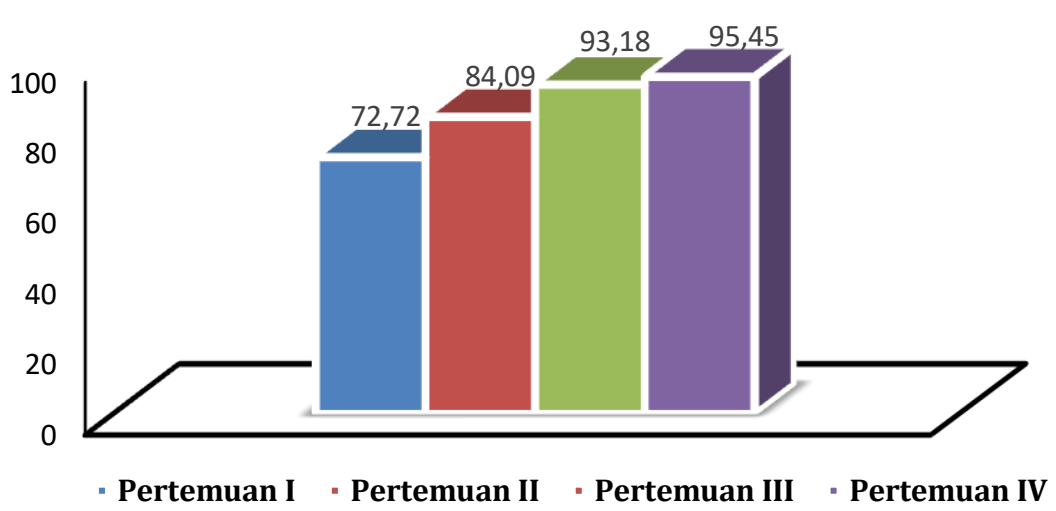

Gambar 3. Hasil observasi model pemebelajaran inkuiri terbimbing integrasi peer instruction terhadap kemampuan berpikir kritis kelas eksperimen

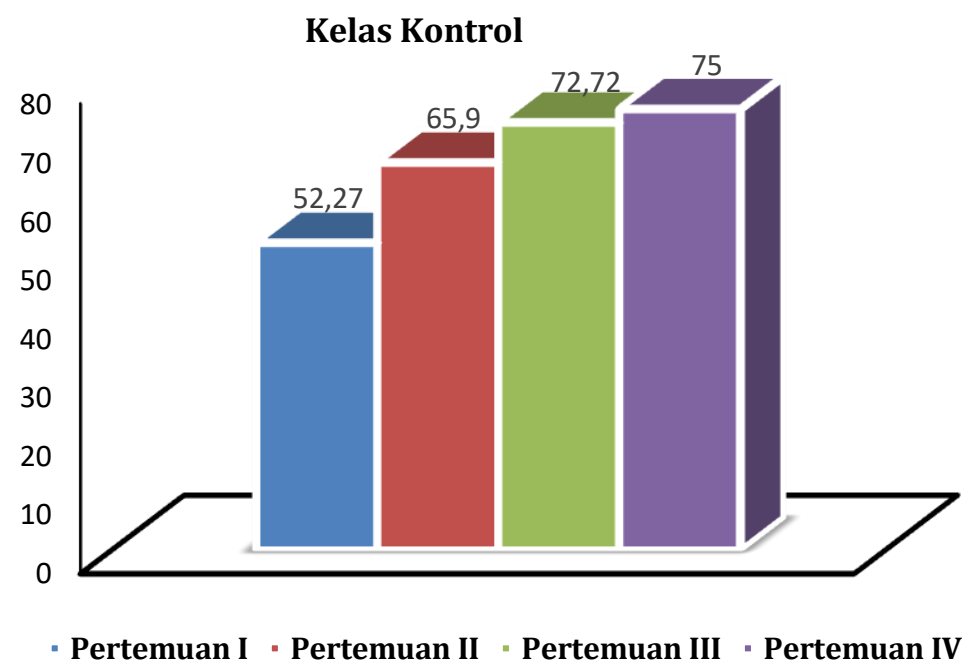

Gambar 4. Hasil observasi pendekatan saintifik terhadap kemampuan berpikir kritis kelas kontrol

Data diatas menunjukan hasil observasi dari pertemuan pertama, kedua, ketiga dan keempat. Data observasi diambil dari masing-masing tahapan model pembelajaran Inkuiri Terbimbing integrasi peer instruction untuk kelas ekperimen dan untuk kelas kontrol hanya digunakan pendekatan saintifik. Analisis data akhir (uji hipotesis) dilakukan dengan uji t dan uji koefisien pengaruh. Akan tetapi, penggunaan uji t tersebut sudah memenuhi syarat yaitu data harus terdistribusi normal. Maka sebelum melakukan Uji t terlebih dahulu dilakukan uji normalitas dan uji homogenitas terhadap nilai posttest siswa. 
Sebelum dilakukan uji hipotesis terlebih dahulu dilakukan uji normalitas data yang berguna untuk memastikan data yang didapat berdistribusi normal. Data normalitas diperoleh dari pengolahan hasil posttest yang diberikan pada kelas eksperimen dan kontrol dengan menggunakan uji chi-kuadrat. Kriteria pengujian normalitas yaitu jika $x_{\text {hitung }}^{2}<x_{\text {tabel }}^{2}$ maka data berdistribusi normal, manun jika $x_{\text {hitung }}^{2}>x_{\text {tabel }}^{2}$ maka data tidak berdistribusi normal.

Hasil uji normalitas didapatkan bahwa $x_{\text {hitung }}^{2}$ kelas eksperimen 11.00 sedangkan $x_{\text {tabel }}^{2}$ untuk $\alpha=5 \%$ adalah 21.026. Dapat dilihat $x^{2}$ hitung lebih kecil dari $x_{\text {tabel }}^{2}(11.00 \leq 21.026)$ artinya data yang didapat berdistribusi secara normal atau sampel berasal dari populasi yang berdistribusi normal. Sedangkan pada kelas kontrol diperoleh nilai $x_{\text {hitung }}^{2}$ sebesar 4.64 sedangkan $x_{\text {tabel }}^{2}$ untuk $\alpha=5 \%$ adalah 21.026. Dapat dilihat $x_{\text {hitung }}^{2}$ lebih kecil dari $x_{\text {tabel }}^{2}(4.64 \leq 21.026)$ artinya data yang didapat berdistribusi secara normal.

Tabe1 2. Hasil analisis data uji normalitas postest

\begin{tabular}{llll}
\hline Kelas & $x^{2}{ }_{\text {hitung }}$ & $x^{2}$ tabel & Kriteria \\
\hline Eksperimen & 11.00 & 21.026 & Normal \\
\hline Kontrol & 4.64 & 21.026 & Normal \\
\hline
\end{tabular}

Uji homogenitas juga dilakukan terhadap nilai postest dari kelas eksperimen dan kelas kontrol. Data homogenitas diperoleh dari pengolahan hasil posttest yang diberikan pada kelas eksperimen dan kontrol dengan menggunakan bantuan software SPSS versi 24.0 dengan menggunakan uji $\mathrm{F}$, dengan melihat nilai $\mathrm{F}_{\text {hitung }}$ yang terdapat pada uji t. Kriteria pengujian untuk uji ini yaitu jika $\mathrm{F}_{\text {hitung }}>\mathrm{F}_{\text {tabel }}$ berarti data tidak homogen, sedangkan jika $\mathrm{F}_{\text {hitung }}<\mathrm{F}_{\text {tabel }}$, maka data homogen. Hasil $\mathrm{F}_{\text {hitung }}$ yang diperoleh adalah sebesar 0.252 Dapat dilihat $\mathrm{F}_{\text {hitung }}$ lebih kecil dari $\mathrm{F}_{\text {tabel }}$ $(0.252<4.04)$ artinya data yang didapat homogen.

Penerapan model inkuiri terbimbing integrasi peer instruction di kelas eksperimen memberikan pengaruh positif barupa peningkatan kemampuan berpikir kritis siswa. Data yang diperoleh dari pengolahan hasil posttest yang diberikan pada kelas eksperimen dan kontrol dengan menggunakan bantuan software SPSS versi 24.0 dengan menggunakan uji independent samples test atau uji beda diperoleh nilai $t_{\text {hitung }} 2,133$. Kriteria pengujian untuk uji ini yaitu jika $t_{\text {hitung }}>t_{\text {tabel }}$ dan $t_{\text {tabel }}$ pada taraf signifikan 5\% dengan demikian $h_{0}$ ditolak dan $h_{a}$ diterima, sedangkan jika $\quad t_{\text {hitung }}<$ $t_{\text {tabel}}$, maka $h_{0}$ diterima dan $h_{a}$ ditolak.

Dari hasil yang didapatkan nilai $t_{\text {hitung }} 2,133$, sedangkan nilai $t_{\text {tabel }}$ yang didapatkan adalah 1,676, maka dapat dilihat $t_{\text {hitung }}$ lebih besar dari $t_{\text {tabel }}(2,133>1,676)$ artinya $h_{a}$ diterima. Kesimpulannya model pembelajaran inkuiri terbimbing integrasi peer instruction dapat meningkatkan kemampuan kognitif siswa pada pokok bahasan laju reaksi di kelas XI MIA Sekolah Menengah Atas Negeri 2 Tapung. Berdasarkan analisis koefisien pengaruh didapatkan pengaruh sebesar $8,4 \%$.

\section{TEMUAN DAN PEMBAHASAN}

Penelitian ini dilaksanakan pada 2 kelas yaitu XI MIA 1 dan XI MIA 2, SMA Negeri 2 Tapung. Pada kelas eksperimen diberi perlakuan menggunakan model pembelajaran inkuiri terbimbing integrasi peer instruction, sedangkan kelas kontrol diberi perlakuan menggunakan pendekatan saintifik. Pembelajaran inquiri terbimbing pada penelitian ini terdiri dari beberapa tahap, yaitu mengajukan pertanyaan (masalah), merancang percobaan, mengumpulkan dan menganalisis data, dan membuat kesimpulan (Fitri \& Fatisa, 2019).

Berdasarkan data yang diperoleh dari hasil penelitian ini, pada kelas eksperimen dan kelas kontrol diperoleh kemampuan berpikir kritis yang berbeda. Hal ini terlihat dari persentase ratarata hasil pencapaian kemampuan berpikir kritis siswa dari kelas eksperimen 66\% dengan kriteria 
kritis sedangkan kelas kontrol sebesar 58.75\% dengan kriteria cukup kritis. Berdasarkan uraian diatas dapat disimpulkan kemampuan berpikir kritis siswa saat pembelajaran kimia pada materi laju reaksi dikelas eksperimen yang menggunakan model pembelajaran inkuiri terbimbing integrasi peer instruction lebih bagus dibandingkan dengan kelas kontrol.

Adapun pengaruh model pembelajaran Inkuiri Terbimbing integrasi Peer Instruction terhadap kemampuan berpikir kritis siswa pada materi laju reaksi kelas XI MIA sebesar 8,4\% didapat dari nilai koefisien pengaruh. Dapat dilihat dari persenan pengaruh yang didiperoleh dapat diartikan bahwa penerapan model pembelajaran inkuiri terbimbing integrasi peer instruction pada materi laju reaksi cukup sesuai untuk melatih kemampuan berpikir kritis siswa, dimana proses pemecahan masalah dilakukan oleh beberapa orang siswa dalam kelompok. Kecenderungan siswa untuk bekerjasama dan berbagi pemikiran dalam suatu kelompok lebih baik dikarenakan pemikiran seseorang dibentuk oleh orang-orang disekitarnya ketimbang apa yang ia alami sendiri (Rahma, 2012).

Berpikir merupakan suatu proses kognitif yaitu aktifitas mental seseorang untuk memperoleh pengetahuan. Berpikir mampu mempersiapkan siswa berpikir pada disiplin ilmu serta dapat dipakai untuk meningkatkan intelektual dan mengembangan potensi siswa. Pembelajaran untuk berpikir adalah pembelajaran yang diarahkan pada penciptaan situasi kelas yang mendorong pengembangan berpikir kognitif. Pengajaran tentang berpikir adalah pengajaran yang kegiatannya diarahkan pada upaya untuk membantu siswa agar lebih sadar terhadap proses berpikirnya. Pembelajaran berpikir merupakan upaya pembelajaran yang memiliki inti pada upaya mengembangkan kemampuan berpikir bagi setiap siswa.

Berpikir kritis adalah merupakan gaya berpikir terhadap suatu masalah dimana siswa dapat meningkatkan kemampuannya dalam berpikir. Paul menyatakan bahwa seseorang tidak hanya sekedar berpikir, tetapi dia juga mampu berpikir mengenai apa yang dipikirkannya atau "thinking about thinking". Dengan demikian berpikir kritis adalah proses berpikir aktif, tentang segala sesuatu untuk diri sendiri, memunculkan pertanyaan untuk diri sendiri, dan memperoleh informasi untuk diri kita sendiri serta cenderung untuk mempertimbangkan dan memikirkan suatu masalah yang timbul dari pengalaman.

Pada indikator 1 yaitu memberikan penjelasan sederhana (Elementary Clarification) dengan rata-rata persentase untuk kelas XI MIA 1 (kelas eksperimen) pada saat Pretest 50,25\% dengan klasifikasi kurang kritis dan Postest 75,64\% dengan klasifikasi kritis. Sedangkan pada kelas XI MIA 2 (kelas kontrol) diperoleh persentase rata-rata pada saat Pretest 50\% dengan klasifikasi kurang kritis dan postest $70,66 \%$ dengan klasifikasi kritis. pada indikator ini terdapat peningkatan yang signifikan antara pretest dan postest hal ini dikarenakan pemilihan model pembelajran inkuiri terbimbing dan metode pembelajaran peer instruction yang tepat pada saat proses pembelajaran berlangsung yang dapat mendorong siswa mengemukakan pandangannya dalam diskusi serta mendiskusikan pendapat mereka kepada teman sejawatnya sehingga siswa lebih leluasaa dan aktif dalam proses pembelajaran.

Pada indikator 2 yaitu membangun keterampilan dasar (Basic Support) dengan rata-rata persentase untuk kelas XI MIA 1 (kelas eksperimen) pada saat Pretest 34,61\% dengan klasifikasi tidak kritis dan Postest 65,38\% dengan klasifikasi cukup kritis. Sedangkan pada kelas XI MIA 2 (kelas kontrol) pada saat Pretest 34,61\% dengan klasifikasi tidak kritis dan postest 55,60\% dengan klasifikasi kurang kritis. pada indikator ini terdapat perbedaan pada saat postest yaitu untuk kelas eksperimen diklasifikasikan cukup kritis sedangkan untuk kelas kontrol diklasifikasikan kurang kritis. Pada indikator ini terjadi peningkatan yang disebabkan semangatnya siswa dalam menjawab sejumlah soal dan memberikan alasan yang logis yang merupakan rangkaian dari kemampuan berpikir kritis siswa (Sumarni, 2017).

Pada indikator 3 yaitu membangun menyimpulkan (Inference) dengan rata-rata persentase untuk kelas XI MIA 1 (kelas eksperimen) pada saat Pretest 30,38\% dengan klasifikasi tidak kritis dan postest 56,92\% dengan klasifikasi cukup kritis. Sedangkan pada kelas XI MIA 2 (kelas kontrol) pada saat pretest $21,92 \%$ dengan klasifikasi tidak kritis dan postest $48 \%$ dengan klasifikasi kurang 
kritis. Pada indikator ini terdapat peningkatan hasil yang menunjukkan siswa cukup baik dalam menyelesaikan suatu permasalahan sehingga siswa bisa menyimpulkan jawaban dari soal yang telah diberikan.

Berdasarkan uraian diatas dapat disimpulkan bahwa kemampuan berpikir kritis siswa pada saat pembelajaran kimia materi laju reaksi di kelas eksperimen yang menggunakan model pembelajaran inkuiri terbimbing integrasi peer instruction lebih bagus dibandingkan dengan kelas kontrol. hal ini dikarenakan pada pembelajaran peer instruction siswa akan disajikan pertanyaan oleh guru dan diberikan kesempatan untuk menjawab pertanyaan tersebut yang kemudian akan didiskusikan bersama teman sekelompok. penggabungan dua pembelajaran tersebut yaitu inkuiri terbimbing dan peer instruction, pada inkuiri terbimbing siswa akan mengkonstruksi pengetahuannya, dengan peer instruction siswa akan mengoptimalkan keaktifannya dalam pembelajaran dengan berdiskusi mengenai permasalahan konsep dengan teman sekelompoknya.

\section{SIMPULAN}

Persentase rata-rata hasil pencapaian kemampuan berpikir kritis siswa dari kelas eksperimen 66\% dengan kriteria kritis sedangkan kelas kontrol sebesar 58.75\% dengan kriteria cukup kritis. Data akhir yang diperoleh dari penelitian ini diuji dengan uji t sebagai uji hipotesis. Hasil yang didapatkan yaitu nilai $t_{\text {hitung }} 2,133$, sedangkan nilai $t_{\text {tabel }}$ yang didapatkan adalah 1,676, maka dapat dilihat $\mathrm{t}_{\text {hitung }}$ lebih besar dari $\mathrm{t}_{\text {tabel }}(2,133>1,676)$ artinya $\mathrm{h}_{\mathrm{a}}$ diterima dan $\mathrm{h}_{0}$ ditolak. Hal ini berarti terdapat pengaruh yang signifikan dari penerapan model pembelajaran inkuiri terbimbing integrasi peer instruction terhadap kemampuan berpikir kritis siswa. Uji koefisien pengaruh juga dilakukan untuk mengetahui besarnya pengaruh penerapan model pembelajaran inkuiri terbimbing terintegrasi peer instruction terhadap kemampuan berpikir kritis siswa, diketahui bahwa besarnya pengaruh yang diberikan adalah $8,4 \%$.

\section{REFERENSI}

Agustin, Y. (2016). Peningkatan Keterampilan Berpikir Kritis Siswa pada Materi Laju Reaksi Melalui Pendekatan Saintifik. Jurnal Pendidikan dan Pemelajaran Kimia, 5(3), 98-112.

Arantika, J., Sahputra, R., \& Sartika, R. P. (2014). Pengaruh Inkuiri Berbantuan Pictorial Riddle terhadap Kemampuan Berpikir Kritis pada Materi Koloid di SMA (Doctoral dissertation, Tanjungpura University).

Loliwa, I. A. N. (2016). Model Inkuiri Terbimbing Integrasi Peer Instruction Disertai LKS Berbasis Multirepresentasi Terhadap Kemampuan Representasi Verbal dan Matematika. Jurnal Pembelajaran Fisika, 4(5), 555-563.

Fajariyah, N., Utami, B., \& Haryono, H. (2016). Penerapan Model Pembelajaran Inkuiri Terbimbing untuk Meningkatkan Kemampuan Berpikir Kritis dan Prestasi Belajar pada Materi Kelarutan dan Hasil Kali Kelarutan Siswa Kelas XI SMA Al Islam 1 Surakarta Tahun Ajaran 2014/2015. Jurnal Pendidikan Kimia (JPK)

Fitri, I., \& Fatisa, Y. (2019). Penerapan Model Pembelajaran Inkuiri Terbimbing untuk Mendukung Kemampuan Literasi Sains Siswa pada Materi Sistem Koloid. Journal of Natural Science and Integration, 2(2), 181-190.

Nur'Azizah, H., Jayadinata, A. K., \& Gusrayani, D. (2016). Pengaruh Model Pembelajaran Inkuiri Terbimbing Terhadap Kemampuan Berpikir Kritis Siswa pada Materi Energi Bunyi. Jurnal Pena Ilmiah, 1(1), 51-60.

Hendra, S. (2011). Strategi Jitu Mencapai Kesuksesan Belajar. Jakarta: Efek Media Komputindo. 
Kartimi. (2013). Alat Ukur Keterampilan Berpikir Kritis Konsep Kimia untk Siswa SMA. Yogyakarta: Deepublish.

Kurniawati, I. D., \& Diantoro, M (2014). Pengaruh Pembelajaran Inkuiri Terbimbing Integrasi Peer Instruction Terhadap Penguasaan Konsep dan Kemampuan Berpikir Kritis Siswa. Jurnal Pendidikan Fisika Indonesia, 10(1), 36-46.

Sulviani, O., Muslimin, M., \& Pasaribu, M. (2013). Pengaruh Peer Instruction dalam Model Pembelajaran Inkuiri Terbimbing Terhadap Keterampilan Berpikir Kritis Pokok Bahasan Usaha Dan Energi Siswa SMAN 2 Sigi. Jurnal Pendidikan Fisika Tadulako (JPFT), 4(4).

Zhou, Q., Ma, L., Huang, N., Liang, Q., Yue, H., \& Peng, T. (2012). integrating Webquest Into Chemistry Classroom Teaching to Promote Students' Critical Thinking. Creative Education, 3(03), 369.

Rahma, A. N. (2012). Pengembangan Perangkat Pembelajaran Model Inkuiri Berpendekatan SETS Materi Kelarutan dan Hasil Kelarutan Untuk Menumbuhkan Keterampilan Berpikir Kritis Dan Empati Siswa Terhadap Lingkungan. Journal of Education Research and Evaluation, 1(2). 133-138

Sumarni., Santoso, B. B., \& Suparman, A. R. (2017). Pengaruh Model Pembelajaran Inkuiri Terbimbing Terhadap Hasil Belajar Kognitif Peserta Didik di SMA Negeri 01 Manokwari (Studi Pada Pokok Bahasan Kelarutan dan Hasil Kali Kelarutan). Jurnal Nalar Pendidikan, 5(1).21-30 